\title{
Islamic Banks: History, Stability and Lessons from Cooperative Banking
}

\author{
Rosana Gulzara, Mansor H. Ibrahim ${ }^{\mathrm{b}}$ \& Mohamed Ariff ${ }^{\mathrm{c}}$
}

\begin{abstract}
Islamic banking's profit-maximising fervour, building upon the use of interest-resembling products, has raised concerns about its Shariah authenticity and financial stability. While early Islamic economists envisioned an industry built on values of mutuality and participation, architects of Islamic banking have chosen to replicate interest-based conventional banking for the purpose of fast growth. This study has two objectives. First, to narrate the history of Islamic banking, from the theories postulated to the beginnings of the industry. This builds an understanding of why 'Islamic' banking operates as it does currently, which has implications for Shariah compliance and financial stability. It is suggested that the mimicking of conventional banks may cause instability since unlike commercial banks, 'Islamic' banks face Shariah constraints. This leads to the second objective, which is to analyse the cooperative banking model, which has been described as the closest theoretical model to Islamic banking. Specifically, this study focuses on the model in Europe which, despite its challenges, has managed to silence critics in the way it contributes to communal welfare and financial stability, especially during credit crunches when commercial banks are known to retreat from markets. This first study of a functioning cooperative banking model, in the context of Islamic banking, may thus offer lessons for Islamic banking reform.
\end{abstract}

Keywords: Cooperative banking; History; Islamic banking; Authenticity; Stability.

JEL Classification: G01, G21, G28

a Corresponding author. Former $\mathrm{PhD}$ candidate. School of Graduate Studies, International Centre for Education in Islamic Finance (INCEIF), Lorong Universiti A, 59100 Kuala Lumpur, Malaysia.Email: rosanagulzar@gmail.com

b School of Graduate Studies, International Centre for Education in Islamic Finance (INCEIF), Lorong Universiti A, 59100 Kuala Lumpur, Malaysia. Email: mansorhi@inceif.org. Orcid ID: 0000-0003-0413-0075

c Faculty of Economics \& Administration, University of Malaya, 50603 Kuala Lumpur. Email: ariff19@um.edu.my 


\section{Introduction}

Islamic banking, as currently practised, has been criticised for being Islamic in all but name (Gulzar, 2016; Azmat et al., 2015; Khan, 2010). 'Islamic' commercial banks maximise profits just like their conventional counterparts at the expense of most other social and environmental considerations. They do this through 'financings' that look like the interest or riba that they are supposed to replace. So, despite the advent of 'Islamic' banking, the industry is still far from the ideals of mutuality, participation, and care for social welfare, as espoused by early scholars of Islamic Economics. In practical terms, this means that countries with 'Islamic' finance markets continue to be caught in a rut of wealth inequality, lack of social mobility and safety nets for the poor (Naceur et al., 2015).

Given these issues, this study has two objectives. First, it narrates the history of Islamic banking, from the theories postulated by early academics to the beginnings of the industry. Understanding the roots will help us comprehend why 'Islamic' banking operates as it currently does, which has implications for financial stability. In mimicking conventional banks, 'Islamic' banks may have brought on the problem of instability since unlike commercial banks, they face Shariah constraints. Relatedly, this study analyses the Malaysian regulator's latest attempt to bridge the divide between theory and practice and how it falls short.

Having covered those issues, this paper proceeds to the second objective, which is to study, for the first time, a lesser-known form of banking in Europe, the cooperative banks, to draw lessons for the reform of Islamic banks. According to scholars such as Chapra (1985), El-Gamal (2006) and Al-Muharrami and Hardy (2013), mutual-based banking, such as that by cooperative banks, is closest to the theoretical model of how Islamic banks should be. Cooperative banks have persisted for over two centuries in mostly commercial banking-dominated markets, so there could be much to learn from a banking model that seems to more closely embody the Shariah ideals that should have underpinned Islamic banking. 


\section{Islamic Banking}

\subsection{Early model based on socio-economics}

Contrary to what some of the textbooks, such as those for the CIMA Diploma in Islamic finance, would have us believe, the industry did not just start in 1975 with the setting up of Dubai Islamic Bank followed by the multilateral, Jeddah-based, Islamic Development Bank. This formal start was in fact preceded by banking experiments in the 1950s and 1960s in Pakistan, Egypt and Malaysia (El-Gamal, 2006; Irfan, 2015). Inspired by the writings of early Islamic thinkers, such as Abu al-A'la al-Mawdudi and the leader of the Muslim Brotherhood Movement in Egypt, Hassan al-Banna, the pilot experiences were based on the socio-economic approach of Islamic finance, which called for social justice and equitable economic opportunities. This was in response to the disconcerting Western influence and colonial insensitivity to Islamic social values in countries under their rule. Paradoxically, the experiments were inspired by the mutual-based institutions that were thriving in the colonists' home region, Europe (Hegazy, 2006).

The socio-economic approach was then advanced by economists such as Khurshid Ahmad, Muhammad Umer Chapra and more recently, Mohammad Nejatullah Siddiqi. Among the tenets propounded by these economists are the profit- and loss-sharing (PLS) contracts such as musharakah and mudarabah, which according to them reflect Islamic principles more than debt financing because of the former's equitable and wealth distributive natures. The term bandied about then was 'two-tier mudarabah', where the profit-sharing contract is to be used on both the deposit and financing sides of an Islamic bank.

The highest profile experiment was by Ahmed El-Najjar, who set up the Mit Ghamr local savings bank in Egypt in 1963. Inspired by the German savings banks, which he witnessed during his graduate studies there and, distressed by issues of poverty and a lack of equal access to credit in Egypt, El-Najjar decided the solution was to mobilise the poors' savings. Collectively, they can finance projects by peasants, artisans and workers that would build the economy. The bank did not charge nor pay interest and shared profits from the small businesses it financed with the investment account holders. The bank would even get involved in the customers' projects if they had a good plan but lacked the skills for implementation. 
In line with the relationship type of banking that characterises European mutual financial institutions, El-Najjar invested time and effort to understand the townspeople's economic problems and traditions. His closeness to customers and societal pressure helped ensure high borrowing repayments, effectively overcoming the notorious moral hazard problem commonly associated with PLS financings. Moral hazard occurs when borrowers take undue risks or become fraudulent because they need not bear most of the costs of default (Mayer, 1985; Hegazy, 2006).

El-Najjar's efforts were welcomed by the villagers whom according to an observer, were deeply grateful for the critical financing. They believed it would not have come from other sources, such as commercial banks (Ready, 1967, p. 20). The reception, however, was not as warm with the local government, whom although approved of the project initially, became wary as the experiment gained traction. It seemed to conflict with their socialist belief in atheism and state ownership of the means of production. The experiment thus lasted a mere four years (Mayer, 1985; Warde, 2010).

As a model, the bank was stable since shocks from one side of the balance sheet could be passed to another. For example, depositors were paid less when the business ventures recorded lower-than-expected profits. And in the case of losses, depositors would bear the brunt in proportion to their capital contributions. Together with Islam's injunctions against profiting from debt, engaging in speculative activities and unethical or fraudulent behaviour, the model was almost fool proof.

Yet, except for Tabung Haji in Malaysia, other early attempts at genuine PLS were plagued by instability and closures. Details are relatively scant in English. From the available literature, the reasons for closure ranged from political - that is fear of an Islamic resurgence and disagreements on how the banks should be regulated - to financial. At least one account in Arabic reported that in the 1980s, Islamic banks in Egypt which extended PLS financings had been defrauded by customers ${ }^{1}$. It is likely that these banks, which used PLS contracts without the necessary safeguards, had attracted customers with either a risky proposition to start with (and were thus attracted by the loss-absorbing or loss-sharing features of PLS) or who under-declared the profit to keep more of it for themselves. In academia, this problem is known as information asymmetry in favour of borrowers, which can then lead to issues of moral hazard and adverse selection, which is the risk of underpricing one's products for customers who in fact, are high risk and vice versa. 


\subsection{The move to the legalistic approach}

In the 1970s, a set of Gulf Cooperation Council (GCC)-based pioneers financed the first group of Islamic banks in Dubai, Kuwait, and Saudi Arabia. This saw the beginning of the legalistic approach when given the sprouting of shaykhs with newfound wealth from the oil boom, the banks decided to be pragmatic and find a way to quickly absorb their savings through permissible ( halāl) financial products. The objective is to remain, as much as possible, within the widely established structures of conventional finance (Hegazy, 2006). 'Success' is thus defined as having as complete a suite of products as the conventional counterparts even though the latter thrive on profiting from debt, which ironically is supposed to be the hallmark prohibition for Islamic banking. The mimicking raises two issues on the banks' Shariah authenticity and financial stability.

\subsubsection{Impacts of mimicking conventional banks}

Riba, or interest, is unanimously condemned by Islamic scholars. The preponderance of debt-like products in 'Islamic' banks from Malaysia to Saudi Arabia, the home of Islam's two holiest sites, has thus led to questions of their Islamicity (Gulzar, 2016; Azmat et al., 2015; Khan, 2010; Chong and Liu, 2009). In Malaysia, as of December 2017, 70\% of financings were through contracts that approximate fixed returns such as murabaha, ijarah and bai bithaman ajil (BNM, 2017b). Saudi Arabia's central bank, SAMA does not provide breakdowns between Islamic and commercial banks but authors such as Hegazy (2006) say $70 \%$ is a fair figure for IFIs (Islamic financial institutions).

Even if we agree with the banks' remunerated Shariah scholars that the contracts used to transform the loans - e.g., commodity murabaha (or tawarruq) and bai bithaman ajil - are Shariah-compliant, the practice runs smack against the theoretical foundation as espoused by early Islamic economists, that is PLS.

In terms of stability, it is even more ironic that 'Islamic' banks are replicating a model, which has at its core, debt creation or making others reliant on the debt it creates. Commercial banks are the engines of the fractional reserve system, whose defining feature, according to several thinkers, is the perpetuation of debt as a stimulus for growth (El Diwany, 
2003; Jha, 2013 and 2014; Mian and Sufi, 2015). When debt levels become unsustainable, the crises that ensue tend to be severe, in impact and reach. In 2010, Europe was almost crippled by a sovereign debt crisis, while Japan suffered a lost decade in the 1990s and some suggest, even until today, with a debt-to-GDP ratio of almost $240 \%$ (OECD, 2021). Debt has thus been identified as the cause of the shortening cycles of booms and busts in the world today and yet 'Islamic' banks are filling up their balance sheets with ever more of them in a joyful replication of the commercial banks.

This however extends beyond products. Academics and industry observers have noted that the banks seem to have lost their soul in the bid for profit maximisation, just like their conventional counterparts, when the early model of PLS was predicated on values such as mutuality, participation, and social welfare (Kuran, 1995; El-Gamal, 2006; Ismail, 2014). This arguably stems from the business model adopted. Being shareholder-driven, the characteristics bred among commercial bankers in the interest-based system are those of self-centredness, greed and short-termism (Kay, 2016). The situation is no different in 'Islamic' banks. In fact, many 'Islamic' bankers were former conventional ones (Khan, 2015; Parker, 2007).

The question thus is, in mimicking commercial banks, have 'Islamic' banks become just as unstable, if not worse? Given that they pursue the same broad strategy of profit maximisation through excessive debt creation, there is no reason to believe that the same will not happen to 'Islamic' banks. The issue, as alluded to earlier, is that Islamic banks may be suffering from a wrong model of implementation. Theoretically, the socio-economic model calls for adherence to values such as mutuality, social, welfare over personal gains, prudence, moderation, and sustainability i.e., long-termism. All of which have been argued to add to stability. In practice however, Islamic banks are being pushed for growth in a model with values antithetical to all the above. In trying to squeeze these square pegs into round holes, it is likely that Islamic banks have become less stable since, unlike commercial banks, they also face Shariah constraints that hamstring parts of their operations, such as the prohibition on trading debt and futures. Commercial banks use these effectively for interbank operations and hedging exposures.

\subsection{Malaysia launches VBI to correct Islamic banks}

The irony is that the more knowledgeable 'Islamic' bankers concede that 
their business model is far from ideal (Haneef, 2016). Yet, they argue that when the industry gains critical mass, they will have the wherewithal to re-navigate the industry towards more genuine Islamic banking practices. This seems to be what Malaysia's central bank, Bank Negara Malaysia (BNM), has in mind when in 2017, it launched an initiative called 'Valuebased intermediation (VBI)'. In an implicit recognition of the limitations of commercial banking as a business model, it urges Islamic banks in Malaysia to cultivate a broader range of objectives beyond profit maximisation (BNM, 2017a). Specifically, as per Figure 1, the proposal calls for a move from "short-term and narrow bottom-line" concerns towards long-term objectives that span three Ps: profit, people, and planet.

Figure 1: Changes Required under VBI

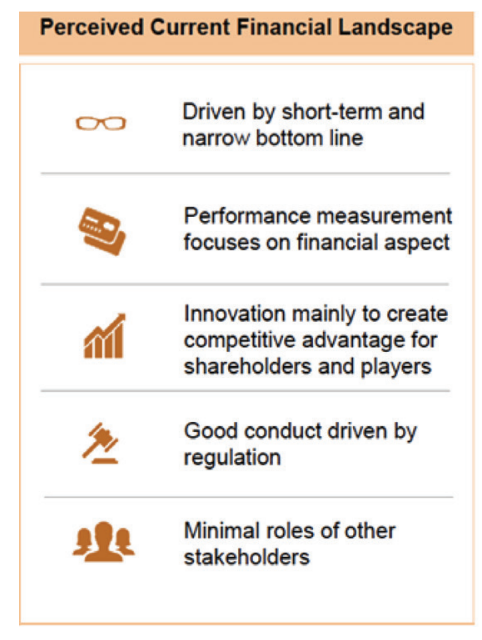

Envisioned Future Financial Landscape
$\begin{aligned} & \text { Driven by long term and } \\ & \text { wider objectives (profit, } \\ & \text { people and planet) }\end{aligned}$
$\begin{aligned} & \text { Performance measurement } \\ & \text { considers both financial } \\ & \text { and non-financial aspects }\end{aligned}$
$\begin{aligned} & \text { Innovation to create values } \\ & \text { for all }\end{aligned}$
$\begin{aligned} & \text { Impact-based approach } \\ & \text { that fosters good conduct }\end{aligned}$
$\begin{aligned} & \text { Meaningful and active roles } \\ & \text { of key stakeholders } \\ & \text { (consumers, employees } \\ & \text { and public) }\end{aligned}$

Source: BNM, 2017a.

This latest initiative by BNM is symptomatic of a trend to frame Islamic finance within the United Nations' Sustainability Development Goals (SDGs), as done also by the Islamic Development Bank and World Bank. While at first look they seem like a natural fit - with goals such as building a sustainable economy with productive employment and decent work for all - a closer look uncovers a fundamental flaw.

VBI seems to gloss over the fact that there are two types of banks. 'Islamic' banks, like the commercial banks they emulate, are known as 
shareholder oriented as they focus on profit maximisation for shareholders. Stakeholder banks, at the other end, have a broader range of objectives that include customers, employees, and the public. This mode of banking is based on relationships, a long-term perspective and is known to put customers' interests first. These banks were frowned upon before the 2008 crisis for being non-mainstream and possibly inefficient, but the 2008 crisis has brought them to the attention of policymakers and regulators for being stable and continuing lending when other banks retrenched in difficult times (von Mettenheim and Butzbach, 2014).

Through VBI, BNM is asking its shareholder-oriented 'Islamic' banks to be more stakeholder-like. What puzzles however is that the central bank maintains its requirement for 'Islamic' banks to be profit-maximising as it highlights in no less than three instances in the July 2017 proposal that the move towards customer and social welfare should come at no expense to shareholders' financial returns (BNM, 2017, p. 1, 6 \& 12). This is puzzling because the literature on stakeholder banks implies a trade-off. They are said to have 'dual bottomlines' because the profit-seeking objective is to be tempered with customer value maximisation.

Some studies thus found that their profits are lower but more stable than commercial banks' (Rabobank, 2009; Chiaramonte et al., 2013; Ferri et al., 2015; Meriläinen, 2016) although it should be noted that empirical studies between stakeholder and shareholder banks are still inconclusive perhaps because of the limited quantity. Thus, some studies have also found that profits by stakeholder banks are higher than commercial banks (Groeneveld, 2014; Ayadi et al., 2010; Ayadi, 2017).

Further, the values that stakeholder banks such as cooperative and savings banks embody are ingrained in the banks, from the ownership structure (customer-owned versus private shareholders) to the type of management. This raises the question of whether VBI can be successful without changing the model and external environment of 'Islamic' banks. The core of current 'Islamic' banking is still debt-churning through what has become 'two-tier murabahah', the cost-plus trade to approximate fixed returns on both sides of the balance sheet. Profiting from debt, as mentioned, is not only un-Islamic but also destabilising.

BNM seems to have anticipated at least the earlier argument. Citing a research, the central bank shows evidence of so-called 'sustainabilityfocused banks' (SFBs) reporting higher profits with less volatility than other 
large banks especially after the 2008 crisis. But there are a number of issues with the research. Firstly, the SFBs are based on very different banking models from the 'Islamic' banks in Malaysia. A check with the original research shows that seven are customer-owned cooperative banks, while another six are either foundation-based or private initiative microfinance institutions. There are seven shareholder-owned commercial banks, somewhat like the 'Islamic' banks in Malaysia, but they tend to have an overt focus on serving the financially excluded segments of the community and not profit maximisation (GABV, 2015) ${ }^{2}$. Using them as benchmarks for the 'Islamic' banks in Malaysia may thus require a change in business model.

The second issue with the research is that it would be a stretch to generalise the results because of the small sample sizes. The study was based on 25 SFBs and 30 large banks from various parts of the world (GABV, 2015). Further, empirical tests on alternative banks, which make up the bulk of the sample, as explained earlier, are still limited and thus inconclusive. Finally, the research is not econometrically robust since the comparison does not take into account extraneous factors, such as the different sizes of the banks and the economic and cultural environments in which they operate. The results are thus still open for debate.

The first objective of this study is therefore to aid the reforms of 'Islamic' banks by going to the roots of Islamic banking. It argues that there is another banking model which is more suitable for the Shariah values espoused by early Islamic banking scholars. In so doing, Islamic banking can become well-loved for its contribution to the community and more importantly, stability of the financial system, something which 'Islamic' banks, at least in theory, are supposed to do.

\section{Cooperative Banks in Europe}

In Europe, the countries host a more diversified banking system made up of commercial banks and mutual institutions such as cooperative and savings banks (Tables 1 and 2). They are at times called 'alternative banks' because their features, from the reasons for founding to the way they operate, are antithetical to the popular, mainstream commercial banks (Butzbach \& von Mettenheim, 2014a). 
Table 1: Composition of Europe's Banking Sector, 2017 (By number of banks)

\begin{tabular}{cccc}
\hline $\begin{array}{c}\text { Country/Business } \\
\text { model }\end{array}$ & $\begin{array}{c}\text { Cooperative } \\
\text { banks }\end{array}$ & $\begin{array}{c}\text { Savings } \\
\text { banks }\end{array}$ & $\begin{array}{c}\text { Commercial } \\
\text { banks }\end{array}$ \\
\hline Germany & 976 & 408 & 261 \\
Austria & 462 & 47 & 50 \\
France & 87 & 0 & 156 \\
\hline Total & 1,525 & 455 & 467 \\
\hline
\end{tabular}

Note: France no longer has any savings banks because in 1999, a group of savings banks called Caisse d'Epargne was converted into cooperative banks due to profitability pressures and criticism of state support (Bülbül et al., 2013).

Source: The above countries' central banks.

Table 2: Composition of Europe's Banking Sector, 2017 (By assets)

\begin{tabular}{cccc}
\hline $\begin{array}{c}\text { Country/Business } \\
\text { model }\end{array}$ & $\begin{array}{c}\text { Cooperative } \\
\text { banks }\end{array}$ & $\begin{array}{c}\text { Savings } \\
\text { banks }\end{array}$ & $\begin{array}{c}\text { Commercial } \\
\text { banks }\end{array}$ \\
\hline Germany & $15 \%$ & $27 \%$ & $40 \%$ \\
Austria & $35 \%$ & $19 \%$ & $27 \%$ \\
\hline
\end{tabular}

Source: The above countries' central banks.

The differences between a cooperative and commercial bank begin from their roots. In nineteenth century Europe, while commercial banks were focused on serving wealthy individuals, large enterprises and governments in urban areas, two Germans were affected enough by the plight of those facing economic hardship to start a movement. The farmers and small business owners in Germany were suffering from the great famine of 1848 and had no access to borrowings except through lenders who charged high rates. A study found that annual rates above $30 \%$ were not uncommon in Germany then (Groeneveld, 2014). Friedrich Wilhelm Raiffeisen (1818-1888), an ascetic Christian, and Hermann Schulze-Delitzsch (1808-1883), a liberal politician, sought to help the grief-stricken farmers and business owners by using the latters' collective power to administer themselves into an organisation. Based on the values of self-help and self-responsibility, the two men each founded cooperative banks, which were to become the network of nearly 1,000 Raiffeisen and Volksbanks (German for 'people's bank') in Germany today. 
The banks thus started as a way of correcting the market failure left by commercial banks and overcoming problems of asymmetric information in favour of borrowers. Before starting a cooperative bank, Raiffeisen had tried helping poor people by financing them through charity from wealthy donors. The institution however failed when borrowers did not repay the loans and donors lost interest (Fonteyne, 2007). Coincidentally, the same issue, asymmetric information in favour of borrowers, seems to have caused the failure of the socio-economic model for Islamic banks. There could thus be lessons for Islamic banking architects and practitioners in the way a cooperative bank is structured from its ownership and governance model to the products and relationship-building with customers.

As the movement grew, cooperative banks became synonymous with values, such as thrift, providing an escape from loan sharks, economic democracy, and stability. The success of cooperative banks in Germany led to their spread across Europe, the Anglo-Saxon world and beyond (Prinz, 2002; Fonteyne, 2007; Rabobank, 2009; von Mettenheim and Butzbach, 2014; "History of Cooperatives," n.d.).

\subsection{Impact on stability}

While the cooperative banking models differ based on each country's history and legislative frameworks, there are a number of defining features. Given the founding objectives, they are structured to be owned by customers, which means that owners are also depositors and borrowers. As owners, they receive member shares which are non-tradable but redeemable. This means that they can only sell their holdings to the bank and no other parties (Schmidt et al., 2014). Another defining feature is in its governance which is considered democratic as it is based on the 'one member, one vote' principle. Further, profit distribution, or dividend, may be limited by law since the objective is to retain profits as accumulated capital in preparation for tough times. Lastly, cooperative banks are mandated to maximise customer benefits, not profits, in the form of return to capital, remuneration on savings and consumer surplus (difference between what a customer is willing to pay and what she pays). These features have been argued to solve, at least in theory, a multitude of problems common in banking, thereby increasing its stability (Fonteyne, 2007; Fonteyne and Hardy, 2011; Groeneveld, 2017). 


\subsubsection{Alignment of interests reduce conflicts}

Banking inherently suffers asymmetries in the access to information and power of decision-making. Banks for example, cannot know to a necessary extent the financial health of their clients or the prospects of their businesses unless the banks invest in costly information-gathering. These asymmetries in turn compound the existing conflicts of interest. Borrowers are tempted to obtain funds and renege on payments. Owners prefer to leverage the balance sheet for maximum profits while managers are inclined to pursue personal gains such as increasing their income, benefits and social status (Fonteyne \& Hardy, 2011).

The cooperative banking model may be especially suited to overcome these conflicts, especially for less wealthy customers in remote locations. There is less of a problem of adversely selecting borrowers since members are incentivised through their stakes in the bank and the voting process to use their strong local ties and soft knowledge to decide which community member has the prerequisite 'credit rating' to receive loans. Borrowers are also less likely to renege since they would be risking their ownership stakes, deposit holdings as well as social and business connections to other members (Fonteyne \& Hardy, 2011).

As for the owners, since they are also depositors in a cooperative bank, they are unlikely to condone leveraging the balance sheet so highly as to jeopardise their deposits. Moral hazard is thus reduced. In a cooperative bank, depositors are also less likely to run at the first sign of trouble since this may destroy their ownership stakes. In fact, deposits often increase at alternative banks during banking crises as customers withdraw from commercial banks. This additional funding thus allows cooperative banks to continue lending to households and businesses in unfavourable times, a stabilising feature that differentiates it from the more procyclical commercial banks (Butzbach \& von Mettenheim, 2014b).

Critics however argue that the agency cost between managers and owners is higher in cooperative banks. Members are less likely to exert oversight on management because ownership is diffused across many members, and each has only one vote. Further, they cannot sell the equity stakes in the market. This makes it easier for management to pursue their own interests, or what is known as expense preference theory. According to the critics, shareholder-oriented banks have at their disposal two ways of 
overcoming this problem; market discipline, or the use of financial markets to rein in manager opportunism, and an internal set of incentives such as share options that can make managers behave as shareholders. Cooperative banks, most of which are non-listed and offer moderate pay packages, lack these tools.

Butzbach and von Mettenheim (2014b) however argue that cooperative banks do have an external disciplining mechanism in the form of networks. These are second-tier organisations that provide auditing and monitoring functions to the local, cooperative banks. As part of joint-liability and cross guarantee schemes that the apex institutions in the networks offer, they can also check on management's fraudulent behaviour, for example, on the use of the banks' free cash flows. The networks thus raise the cooperative banks' stability and efficiency as they provide economies of scale while reducing the risks that an individual cooperative faces due to its small size and homogenous customer base.

As for the internal monitoring device, the 2008 crisis has shown that top management with multimillion stock option plans were not those least willing to use high risk strategies at the banks' expense. The efficacy of the 'incentives', which are costly in the first place, are thus questionable.

More intricately, the asymmetric problems are overcome through the ownership structure that holds together stakeholders (owners, depositors, and borrowers) by merging their interests and the remuneration of deposits, which are based on the cooperative's profitability (Fonteyne and Hardy, 2011). Islamic banking researchers should at this juncture be reminded of the musharakah concept being at work here since cooperative banks are founded to support the economic undertakings of their customers. So, deposits are pooled to finance the needs of small enterprises and households, the profits of which will flow back to the depositors while losses are borne by all.

The alignment of interests thus leads to a more stable banking model since it alleviates some of the conflicts that arise from the asymmetries in banking. 'Islamic' banks tried implementing mudarabah, another type of PLS contract, through a product called 'investment account' but none have been in accordance with the true spirits of PLS. The product tends to be a poorer substitute of its guaranteed, fixed rate deposit cousin (Chong and Liu, 2009; Charap and Cevik, 2011). 


\subsubsection{Other stabilising features}

There are other in-built features of cooperative banks that are uncannily Shariah-like, a confluence of which has allowed cooperative banks to keep a long-term and risk-averse view. Firstly, as mentioned, since the model is based on relationships, a key competitive advantage is customer trust and loyalty built over the lifetime. This means that customers stick with them through thick and thin, allowing the banks to continue lending to households and small businesses even during credit crunches. The 'cost' of building the relationships is having a dense network of branches, which allows the cooperative banks to be physically close to customers even in remote and less profitable areas such as rural provinces and the countryside. But this effectively forces management to think long term, over which the investment will be recouped (Groeneveld, 2014).

Yet another stabilising feature is the way cooperative banks accumulate capital. A significant part of their net profits is added to reserves, known as an intergenerational endowment. In fact, cooperative banks are known to accumulate capital at a lower cost than shareholder banks because they only need to remunerate the portion of reserves that are the members' capital. Even then, the percentage of dividends, as mentioned, is often limited by law. This allows them to reach comfortable levels of liquidity and become net lenders in the interbank market. Rating agencies note these features, together with the banks' legally binding collective guarantee schemes which reduce the risk of an individual bank failure. They are therefore highly rated (Table 3) which is useful if they need further funding through a listed subsidiary for those with one (Fonteyne, 2007; Groeneveld, 2014; Butzbach and Mettenheim, 2014b).

Table 3: Ratings of Cooperative and Commercial Banks in Europe

\begin{tabular}{lcc}
\hline \multicolumn{1}{c}{ Bank } & Type & Fitch \\
\hline Germany & Cooperative & AA- \\
BVR & Commercial & BBB + \\
Deutsche Bank & & \\
\hline Austria & Cooperative & BBB- \\
Volksbanken Verbund & Commercial & A- \\
Erste Group Bank & & \\
\hline
\end{tabular}




\begin{tabular}{lll}
\hline \multicolumn{1}{c}{ Bank } & Type & Fitch \\
\hline France & & \\
Banques Populaire & Cooperative & A \\
Société Générale & Commercial & A \\
\hline
\end{tabular}

Notes: The Austrian networks of cooperative banks suffered considerably during the 2008 crisis due to their expansion into Central, Eastern, and Southern Europe in search of higher returns. They strayed from the cooperative principles by acquiring commercial banks there and had to be bailed out by the government (Fonteyne \& Hardy, 2011). Source: FitchConnect. Ratings are of the latest in 2017.

\subsection{Challenges}

Yet a cooperative banking model is not without challenges. First is the ultra-low, in some cases even negative, nominal interest rates in Europe. In response to the sluggish economies, the European Central Bank (ECB) slashed the deposit rate to $-0.4 \%$ in March 2016 and cut the main lending rate to zero. This squeezes the banks' profits because they earn from the spread between short-term deposits and long-term lending but given the topsy-turvy rates, the banks are trying to hold off charging savers in what would be a radical departure from the norms of banking. On the other hand, the rates that they can charge for loans have been falling ("German banks: Turn of the screw", 2016; Coppola, 2016).

While this is detrimental for all banks in Europe, the cooperative banks are especially hit because three quarters of their earnings come from the interest differential (EACB, 2016). A stress test by the Deutsche Bundesbank, the German central bank, in 2017 even found that if rates remain this low, the profits of the smaller German banks could fall by $16 \%$ by 2021 or in a worst-case scenario, up to $60 \%$ (Bundesbank, 2017).

The second challenge that cooperative banks face is the burgeoning regulations post 2008. While acknowledging their role in increasing the soundness of the European financial system, cooperative banks in Europe say the broad-brush regulations unfairly 'penalise' smaller banks for the mistakes of the larger and less conservative commercial banks. In response to new ECB requirements for higher disclosures, capital and liquidity buffers, the European Association of Cooperative Banks' (EACB) president has called for regulations which take into account the banks' different sizes 
and business models. An ECB representative responded by saying that the rules are indeed more accommodative, and this is clear if they are compared against the large banks' and not the cooperative banks' own volume of regulations in the past (ECB, 2017).

Besides new regulations, cooperative banks are also squeezed through competition from digitalisation. Disruptive technologies, such as mobile payments and money transfers, offer banking services swiftly and costeffectively at customers' fingertips. This compares to the cooperative's high-cost branch networks. According to the EACB president, DZ Bank, the cooperative's apex organisation in Germany, is coordinating the local banks' efforts to move into digital banking. They are investing substantially to increase distribution channels, create new products and win new customers. While this raises current costs, the president is hopeful that digitalisation can simplify the banks' processes and eventually reduce expenditures (EACB, 2016). This, together with the cooperative banks' uncanny ability to survive for almost two centuries, may just help them to silence critics once again.

\section{Islamic Financial Cooperatives}

Cooperative banks in Europe, which seem to imbibe more of the Shariah values that should have underpinned Islamic banking, may thus offer lessons for Islamic banking reform. What is perhaps needed is Islamic cooperative, and not commercial, banks.

Interestingly, there are Islamic financial cooperatives in Muslimmajority countries where Islamic banking is practiced. But they seem far from their potential. In Malaysia for example, the cooperatives sector is underperforming, has issues with governance and is neglected (Othman et al., 2013; "Banking on co-ops", 2018). The country boasts two 'Islamic' cooperative banks and 583 credit unions (Malaysia Co-operative Societies Commission [SKM], n.d.). But the biggest of them all, in terms of assets and revenue, Bank Rakyat, shows similar tendencies as other 'Islamic' banks in Malaysia, of profiting from debt through controversial Shariah contracts. Its 2019 financial statements show that income is mainly from loans structured using tawarruq and bai' al- 'inah, the latter of which is outlawed in the Middle East (Bank Rakyat, 2020).

Broadly, the financial cooperatives in Malaysia seem to be suffering 
from mission drift, a phenomenon where microfinance institutions extend larger loans to wealthier clients at the expense of poorer customers (Beatriz and Marc, 2011). In a financial services sector development plan for 2016-2020, SKM calls the cooperative banks and smaller credit unions in Malaysia to refocus on maximising customer value, and not profits. In a broader masterplan, the National Cooperative Policy for 2011-2020, SKM sets targets for the cooperatives sector to contribute 5\% of Malaysia's Gross Domestic Product (GDP) by 2013 and $10 \%$ in 2020. In 2018, the contribution rate is reportedly only $3 \%$ to $4 \%$ ("Banking on co-ops", 2018). So, in Malaysia, the model for cooperative banking, Islamic and otherwise, seems itself in need of reforms.

Indonesia holds more promise. Alongside its Islamic (commercial) banking industry, which for a decade, stagnated at the 5\% penetration rate $^{3}$, is a form of community-based finance. While still miniscule in market share ${ }^{4}$, its role in supporting the poor and micro, small and medium enterprises (MSMEs) seem to have cast it into the limelight with President Joko Widodo's administration (KNKS, 2018). Indonesia is littered with many small houses of finance called Baitul Maal wat Tamwil (BMT).

A BMT is an Islamic cooperative that combines social and commercial finance. Baitul maal (BM), which translates to 'house of wealth', accepts, and disburses zakat (alms), waqf (endowments) and charities. Baitut tamwil (BT), on the other hand, which refers to 'house of finance', collects deposits and member funds to issue financings based on PLS and (genuine) murabaha. The striking feature about the BMTs is their proximity to the European model of cooperative banking, particularly in Germany. In Indonesia, they are set up to foster self-reliance among the poor through the pooling of resources so that profits and losses can be shared. The partnership also includes mentorships for MSMEs on business know-hows, accounting, and marketing (KNKS, 2019).

The going is not always smooth, however. Some BMTs have collapsed due to managements' spending sprees on posh offices and company cars. Managers are also tempted by the accumulating deposits to invest in risky financial products, which is against the philosophy of cooperative banks. To keep these in check, Indonesia's Ministry of Cooperatives and SMEs says it conducts regular financial 'health assessments' to detect warning signs (KNKS, 2019). Additionally, this is where Indonesia may benefit from the German experience of an apex institution which reduces fraud among 
cooperative banks by providing them with auditing and monitoring services.

Ascarya (2017) also calls for BMs to be better integrated with BTs so the latter may be less afflicted with credit crunches. Member deposits are at times, insufficient to meet demands for microfinancing while Islamic bank financings are costly. The mismatch worsens during peak periods such as the start of school years and festive periods such as Eid. To boost BTs' capital, Ascarya (2017) proposes that the indirect cash waqf (Islamic endowment), received through the BMs, be channelled to BTs so they can issue more financing. Indirect cash waqf can be used to develop micro enterprises because its donors do not state specific uses for the endowments as opposed to direct cash waqf, but the capital needs to be preserved, as per Islamic law. This, Ascarya suggests, can be done through micro-takaful. Currently, although the two houses of finance sit under one roof, they tend to operate parallel to each other when the Islamic Banking Act 2008 does not bar their joint operations.

Legally also, Sakti (2019) highlights the disjointed way the sector is regulated with overlaps between the Ministry of Cooperatives and SMEs and the Financial Services Authority (FSA). This can cause arbitration risk. Given that BMTs support MSMEs, which according to the Ministry of Cooperatives and SMEs, contribute over $60 \%$ of Indonesia's GDP in 2017 (KEMENKOPUKM, n.d.), and the fact that BMTs are different from established financial institutions such as commercial banks, Sakti (2019) calls for better coordination between the ministry, FSA and the National Zakah Board.

Despite these issues, since their beginnings in the early 1990s, there are 4,500 BMTs in 2015, serving almost 4 million people with assets of around 16 trillion rupiah (KNKS, 2019). The sector is admittedly still miniscule if set against Indonesia's population of 261 million people and total banking assets of 6,234 trillion rupiah in 2015 (Financial Services Authority, 2015). The fact however that BMTs made it to President Widodo's masterplan for Indonesia's Islamic Economy, 2019-2024, means that the sector is recognised as having more potential than is currently realised.

Indonesia may be a few steps ahead because it is a former Dutch colony. When the British took over countries such as Malaysia and Pakistan, it enacted its interpretation of the German cooperative model, which included some key diversions in core principles. Instead of pooling the savings of the poor, the British used cooperatives to transfer state credit and subsidies for 
developmental policies. Subsequent degeneration in governance in countries such as Malaysia led to the whittling away of their cooperatives sector, which is premised firstly, on good governance and guaranteed civil rights (Khafagy, 2020). It may thus be worthwhile to study whether the Indonesian model of BMTs, issues notwithstanding, are suitable for export to other Islamic finance countries.

\section{Conclusion}

This paper is among the first attempts to compare Islamic with cooperative banks, from the reasons of their founding to the ways they operate and the current trends. In so doing, it highlights that in mimicking conventional banks, Islamic banks may have jeopardised not only perceptions of its Shariah authenticity but also its stability. BNM's efforts to correct this, while commendable, may end up fruitless if underlying issues of banking model and the type of personnel, business operations and products, are not addressed.

In fulfilling the next objective, this paper throws light on a banking model that may be more feasible for the implementation of the PLS model espoused by early Islamic economists. In fact, the cooperative banks in Europe show that PLS can work if proper safeguards are instituted to reduce problems brought on by the asymmetry of information in banking. ElNajjar's Mit Ghamr savings bank, which was based on the European model, is an example. It closed due to political resentment rather than an inherent flaw. In this post-crisis era of digitalisation however, cooperative banks are facing new challenges. Studies that provide constructive solutions will thus be useful not just for the cooperative banks, but also 'Islamic' banks, which we argue, should more resemble the cooperative banks. Indonesia's BMTs may be paving the way.

\section{Notes}

1 Hegazy (2006) cites an Arabic source: Muhammad 'Abd al-Mun'im Abu Zayd, Nahwa Tatwir Nidham al-Mudaraba fi al-Masarif alIslamiyya 107 (Cairo: al-Ma'had al-'Alami lil-Fikr al-Islami, 2000).

2 GABV stands for Global Alliance for Banking on Values. 
3 In terms of market share by assets ("Shariah banking: Indonesia's 'bold plans' for a troubled industry”, 2019).

4 An estimated $0.26 \%$ of total banking assets in 2015 (KNKS, 2019, p. 3; Financial Services Authority, 2015).

\section{References}

Al-Muharrami, S. M., \& Hardy, D. (2013). Cooperative and Islamic Banks: What can they learn from each other? International Monetary Fund. Retrieved from https://www.imf.org/external/pubs/ft/wp/2013/wp13184. pdf.

Ascarya. (2017). Baitul maal wat tamwil (BMT): An integrated Islamic social and commercial financial institution in Indonesia. ISRA-Thomson Reuters Islamic Commercial Law Report 2018, 104-107. Retrieved from https://ifikr.isra.my/library/pub/9627/isra-thomson-reuters-islamiccommercial-law-report-2018.

Ayadi, R., Llewellyn, D. T., Schmidt, R. H., Arbak, E., \& Pieter De Groen, W. (2010). Investigating diversity in the banking sector in Europe: Key developments, performance and role of cooperative banks. Centre for European Policy Studies. Retrieved from https://www.ceps.eu/ ceps-publications/investigating-diversity-banking-sector-europe-keydevelopments-performance-and-role/.

Ayadi, R. (2017). Banks' business models in Europe: Are cooperative banks different? In Miklaszewska, E. (Ed.), Institutional Diversity in Banking: Small Country, Small Bank Perspectives. (pp. 51-72). Springer International Publishing.

Azmat, S., Skully, M., \& Brown, K. (2015). Can Islamic banking ever become Islamic?. Pacific-Basin Finance Journal, 34: 253-272. https:// doi.org/10.1016/j.pacfin.2015.03.001.

Banking on co-ops to boost economy (2018). The Star. July 17. Retrieved from https://www.thestar.com.my/news/nation/2018/07/17/banking-oncoops-to-boost-economy.

Bank Rakyat. (2020). Financial statements of Bank Kerjasama Rakyat Malaysia Berhad for the year ended 31 Dec 2019. Retrieved from https://www.bankrakyat.com.my/d/about/financial_info/76/attach/ Bank\%20Rakyat\%20Financial\%20Statement\%202019.pdf. 
Beatriz, A., \& Marc, L. (Eds.). (2011). The Handbook of Microfinance. World Scientific.

BNM. (2017a). "Strategy Paper on Value-based Intermediation: Strengthening the Roles and Impact of Islamic Finance". July 20. Retrieved from http://www.bnm.gov.my/index.php?ch=en announcement\&pg=en_announcement\&ac=555

BNM. (2017b). BNM Monthly Statistics 1.18.2 Islamic Banking System: Financing by Concept. Retrieved from https://www.bnm.gov.my/-/ monthly-highlights-and-statistics-december-2017

Bülbül, D., Schmidt, R. H., \& Schüwer, U. (2013). Savings banks and cooperative banks in Europe (No. 5). White Paper Series. Retrieved from https://safe-frankfurt.de/uploads/media/Schmidt_Buelbuel_Schuewer_ Savings_Banks_and_Cooperative_Banks_in_Europe.pdf.

Bundesbank. (2017). Results of the 2017 low-interest-rate survey [PDF file]. August 30. Retrieved from https://www.bundesbank.de/Redaktion/ EN/Downloads/Topics/2017_08_30_press_conference_praesentation. pdf? _ blob=publicationFile.

Butzbach, O \& von Mettenheim, K. (2014a). Introduction. In Butzbach, O \& von Mettenheim, K. (Eds.), Alternative Banking and Financial Crisis (pp. 1-9). Pickering \& Chatto.

Butzbach, O \& von Mettenheim, K. (2014b). Explaining the competitive advantage of alternative banks: Towards an alternative banking theory?. In Butzbach, $\mathrm{O} \&$ von Mettenheim, K. (Eds.), Alternative Banking and Financial Crisis (pp. 51-69). Pickering \& Chatto.

Chapra, M. U. (1985). Towards a just monetary system (Vol. 8). International Institute of Islamic Thought (IIIT).

Charap, J., \& Cevik, S. (2011). The behaviour of conventional and Islamic bank deposit returns in Malaysia and Turkey. IMF Working Paper, WP/11/56. Retrieved from https:/www.imf.org/en/Publications/WP/ Issues/2016/12/31/The-Behavior-of-Conventional-and-Islamic-BankDeposit-Returns-in-Malaysia-and-Turkey-25017.

Chiaramonte, L., Poli, F., \& Oriani, M. E. (2013). Are cooperative banks a lever for promoting bank stability? Evidence from the recent financial crisis in OECD countries. European Financial Management, 21(3), 491523. https://doi.org/10.1111/j.1468-036X.2013.12026.x.

Chong, B. S., \& Liu, M. H. (2009). Islamic banking: interest-free or interestbased? Pacific-Basin Finance Journal, 17(1), 125-144. https://doi. 
$\operatorname{org} / 10.1016 /$ j.pacfin.2007.12.003

Coppola, F. (2016). How should co-operative banks deal with the negative rates dilemma? Coop news. October 5. Retrieved from https://www. thenews.coop/109397/sector/banking-and-insurance/co-operative-banksdeal-negative-rates-dilemma/

EACB (European Association of Cooperative Banks). (2016). Challenges and Opportunities for Co-operative Banks in a World of Change. [PDF file]. May 15. Retrieved from https://www.google.com.sg/ url $? \mathrm{sa}=\mathrm{t} \& \mathrm{rct}=\mathrm{j} \& \mathrm{q}=\& \mathrm{esrc}=\mathrm{s} \&$ source $=$ web $\& \mathrm{~cd}=6 \& \mathrm{cad}=\mathrm{rja} \&$ uact $=8 \& \mathrm{v}$ ed=0ahUKEwjeg_v425zZAhWDNI8KHVDvAA8QFghIMAU\&url=ht tp $\% 3 \mathrm{~A} \% 2 \mathrm{~F} \% 2 \mathrm{Fwww}$.giovanisocibcc.it\%2Fdoc\%2FscaricaDoc.asp $\% 3$ FiDocumentoID\%3D409874\%26iAllegatoID\%3D0\&usg=AOvVaw1cj uv-Lj54NAl-jrxUZDyM

ECB. (2017). 3-6-3: Banks and change. May 21. Retrieved from https:// www.ecb.europa.eu/press/key/date/2017/html/ecb.sp170531_1.en.html

El Diwany, T. (2003). The Problem with Interest. Kreatoc.

El-Gamal, M. A. (2006). Islamic Finance: Law, Economics, and Practice. Cambridge University Press.

Ferri, G., Kalmi, P., \& Kerola, E. (2015). Organizational structure and performance in European banks: A reassessment. In Kauhanen. A. (Ed.), Advances in the Economic Analysis of Participatory \& Labor-managed Firms (pp. 109-141). Emerald Group Publishing Limited.

Financial Services Authority. (2015). Indonesian Banking Statistics December 2015. Retrieved from https://www.ojk.go.id/en/kanal/ perbankan/data-dan-statistik/statistik-perbankan-indonesia/Pages/ Indonesia-Banking-Statistics---Oktober-2014---Desember-2015.aspx.

Fonteyne, M. W. (2007). Cooperative banks in Europe: policy issues (No. 7-159). International Monetary Fund. Retrieved from https://www. imf.org/en/Publications/WP/Issues/2016/12/31/Cooperative-Banks-inEurope-Policy-Issues-21047.

Fonteyne, W., \& Hardy, D. C. (2011). Cooperative banking and ethics: past, present and future. Ethical perspectives-Katholieke Universiteit Leuven, 18(4), 491-514. Retrieved from http://www.ethical-perspectives.be/page. php?FILE=ep_detail\&ID=151\&TID=1346.

GABV. (2015). "Real Economy-Real Returns. The Power of Sustainabilityfocused Banking." Retrieved from http://www.gabv.org/wp-content/ uploads/GABV-Research-Real-Economies-Real-Returns-2015.pdf. 
German banks: Turn of the screw. Ultra-low interest rates are slowly squeezing Germany's banks. (2016) The Economist. June 25. Retrieved from http://www.economist.com/news/finance-and-economics/21701148ultra-low-interest-rates-are-slowly-squeezing-germanys-banks-turnscrew.

Groeneveld, H. (2014). A qualitative and statistical analysis of European cooperative banking groups. In Butzbach, $\mathrm{O} \&$ von Mettenheim, K. (Eds.), Alternative Banking and Financial Crisis (pp. 71-100). Pickering \& Chatto.

Groeneveld, H.M. (2017). European co-operative banks in 2016: a concise assessment. Retrieved from http://www.eacb.coop/en/studies/externalstudies/european-co-operative-banks-in-2016-a-concise-assessment-tiasschool-for-business-amp-society.html.

Gulzar, R. (2016) "German Banks: More Islamic than Islamic banks?" NUS-MEI Islamic Finance Special. Retrieved from https://mei.nus.edu. $\mathrm{sg} /$ publication/insight-ifs-3-german-banks-more-islamic-than-islamicbanks/.

Haneef, R. (2016). Challenges in innovation for Islamic finance product development. ISRA-Thomson Reuters Islamic Commercial Law Report 2016, 122-124. Retrieved from https://ifikr.isra.my/library/pub/7982.

Hegazy, W. S. (2006). Contemporary Islamic finance: From socioeconomic idealism to pure legalism. Chicago Journal of International Law, 7, 581. Retrieved from https://chicagounbound.uchicago.edu/cjil/vol7/iss2/13/.

History of cooperatives. (n.d.). Retrieved from https://www.dgrv.de/en/ cooperatives/historyofcooperatives.html

Irfan, H. (2015). Heaven's Bankers: Inside the Hidden World of Islamic Finance. The Overlook Press.

Ismail, A. H. (2014). Public Lecture by Dato Dr Abdul Halim Ismail, Award Recipient of The Royal Award for Islamic Finance 2014 At the GIFF 2014. Retrieved from http://www.mifc.com/index.php?ch=ch_contents media_centre\&pg $=$ pg_media_centre $\& a c=6013$

Jha, Y. (2013). From Goldsmiths to Modern Banking: A Frank Look at Money-Creation Process and Its Relevance to Islamic Banking. Islam and Civilisational Renewal (ICR), 4(3). Retrieved from https://www. icrjournal.org/icr/index.php/icr/article/view/333.

Jha, Y. (2014). The Destructive Logic of Interest: The Fallacy of Perpetual Growth (With a Discussion of Reformist Action by Islamic Bank). Islam 
and Civilisational Renewal (ICR), 5(3). Retrieved from https://www. icrjournal.org/icr/index.php/icr/article/view/434.

Kay, J. (2016). Other People's Money: Masters of the Universe or Servants of the People? Profile Books Limited.

KEMENKOPUKM. (n.d.). Perkembangan data usaha mikro, kecik, menengah (UMKM) dan usaha besar (UB) Tahun 2017 - 2018. Retrieved from https://www.kemenkopukm.go.id/uploads/laporan/1580223129_ PERKEMBANGAN \%20DATA \%20USA HA \% 20 MIKR O, \% 20 KECIL,\%20MENENGAH\%20(UMKM)\%20DAN\%20USAHA\%20 BESAR\%20(UB)\%20TAHUN\%202017\%20-\%202018.pdf

Khafagy, A. (2020). The Economics of Financial Cooperatives: Income Distribution, Political Economy and Regulation. New York, NY: Routledge.

Khan, F. (2010). How "Islamic" is Islamic Banking? Journal of Economic Behavior and Organization, 76, 805-820. https://doi.org/10.1016/j. jebo.2010.09.015

Khan, T. N. (2015). Closing the gaps of human resource in Islamic banks: literature review analysis. International Journal of Business and Social Science, 6(5), 168-181. Retrieved from http://ijbssnet.com/journals/ Vol_6_No_5_May_2015/19.pdf.

KNKS. (2018). Indonesia Islamic Economic Masterplan 2019-2024. Retrieved from https://knks.go.id/storage/upload/1560308022Indonesia\%20Islamic\%20Economic\%20Masterplan\%202019-2024.pdf. KNKS. (2019). "Enhancement of Micro, Small and Medium Enterprises (MSMEs) through Islamic Cooperatives (BMT)," INSIGHT, Islamic Economy Bulletin. July. Retrieved from https://knks.go.id/storage/ upload/1563795796-INSIGHT\%20-\%202nd\%20Edition-compressed.pdf.

Kuran, T. (1995). Islamic economics and the Islamic subeconomy. The Journal of Economic Perspectives, 9(4), 155-173. DOI: 10.1257/ jep.9.4.155.

Malaysia Co-operative Societies Commission (SKM). (n.d.). Co-operatives Sector Economic Report 2018. Retrieved from https://www.skm.gov. my/index.php/en/pusat-media/penerbitan/laporan-ekonomi-sektorkoperasi-2018.

Mayer, A. E. (1985). Islamic banking and credit policies in the Sadat era: The social origins of Islamic banking in Egypt. Arab Law Quarterly, 1(1): 32. https://doi.org/10.1163/157302585X00383 
Meriläinen, J. M. (2016). Lending growth during the financial crisis and the sovereign debt crisis: The role of bank ownership type. Journal of International Financial Markets, Institutions and Money, 41, 168-182. https://doi.org/10.1016/j.intfin.2015.12.011.

Mian, A., \& Sufi, A. (2015). House of Debt: How They (and you) Caused the Great Recession, and How We Can Prevent it from Happening Again. University of Chicago Press.

Naceur, M. S. B., Barajas, M. A., \& Massara, M. A. (2015). Can Islamic banking increase financial inclusion? (No. 15-31). International Monetary Fund. Retrieved from https://www.imf.org/en/Publications/ WP/Issues/2016/12/31/Can-Islamic-Banking-Increase-FinancialInclusion-42710.

OECD. (2021). General government debt (indicator). DOI: 10.1787/ a0528cc2-en

Othman, I. W., Mohamad, M., \& Abdullah, A. (2013). Cooperative Movements in Malaysia: The Issue of Governance. International Journal of Social, Behavioral, Educational, Economic, Business and Industrial Engineering, 7(6). World Academy of Science, Engineering and Technology (WASET).

Parker, M. (2007). Human Resources in Islamic Banking. Arab News. January 8. . Retrieved from http://www.arabnews.com/node/293073

Prinz, M. (2002). 'German rural cooperatives, Friedrich-Wilhelm Raiffeisen and the organization of trust 1850-1914', In XIII IEHA Congress Paper Buenos Aires, Session (Vol. 57).

Rabobank. (2009). Cooperative banks in the new financial system [PDF file]. Retrieved from https://economics.rabobank.com/PageFiles/629/ cooperatiestudie-200910_tcm64-94102.pdf

Ready, R. K. (1967). Interest-free Banks and Social Change: A Study of the Town of Mit Ghamr, the Village of Dondait and the Mit Ghamr Savings Bank Project (Interest-Free Local Banks). Unpublished manuscript.

Sakti, A. (2019). Towards an effective legal and regulatory framework for Islamic cooperatives (Baitul maat wat-tamwil/BMT) in Indonesia. INSIGHT, Islamic Economy Bulletin, Edisi kedua, July. 12-16.

Schmidt, R. H., Bülbül, D., \& Schüwer, U. (2014). The persistence of the three-pillar banking system in Germany. In Butzbach, O \& von Mettenheim, K. (Eds.), Alternative Banking and Financial Crisis (pp. 101-122). Pickering \& Chatto. 
Shariah banking: Indonesia's 'bold plans' for a troubled industry (2019), Nikkei Asian Review. October 21. Retrieved from https://asia.nikkei.com/ Business/Business-trends/Shariah-banking-Indonesia-s-bold-plans-for-atroubled-industry.

von Mettenheim, K., \& Butzbach, O. (2014). Alternative Banking History. In Butzbach, $\mathrm{O} \&$ von Mettenheim, K. (Eds.), Alternative Banking and Financial Crisis (pp. 11-27). Pickering \& Chatto.

Warde, I. (2010). Islamic Finance in the Global Economy. Edinburgh University Press. 